\title{
Students' and Teachers' Perception on Reward in Online English Teaching Context
}

\author{
N.M.S.D. Saraswati1, *, N.M. Ratminingsih ${ }^{2}$, IG.A.L.P. Utami ${ }^{3}$
}

1,2,3 English Education Department, Postgraduate Program Ganesha University of Education, Singaraja. Indonesia

A R T I C L E I N F O

Article history:

Received February

2020

Received in revised

Form 01 March 2020

Accepted 18 July 2020

Available online 30

August 2020

Keywords:

rewarding, perception,

teaching English online

\section{A B S T R A C T}

Rewarding is one of the factors that influence student learning outcomes so it is important to describe the reward given by the teacher, the teacher's perception of the reward and the student's perception of the reward given by the teacher. This qualitative study aimed to investigate the types of rewards used in teaching English online; frequency of rewarding by teachers in online learning; in what context the reward is given and for what purpose; how teachers perceive rewards in online learning; and how students perceive rewards in online classrooms. The subjects of this study were 116 people consisting of 112 first grade students and 4 first grade teachers. To collect data, there were 3 methods used, namely: observation, recording and taking note. Meanwhile, the main instrument was the researcher himself who was assisted by additional instruments, questionnaires and observation sheets. The collected data were analyzed qualitatively with the Miles and Hubberman model. The results of this study are 1) the teacher gives verbal and object rewards, 2) verbal rewards are more often given, 3) there are three contexts of giving rewards, namely: perfect, almost perfect and needs improvement with different goals, 4) teacher perceptions show giving rewards have a positive influence in academic and non-academic students and 5) students' perceptions of rewards are that they are very happy and motivated after receiving a reward. These results have implications for designing rewards to be diverse and creative to motivate students.

\section{Introduction}

The proliferation of teaching English to young learners issues can be observed in Badung regency. Based on the pre-observation in the area of Kuta Utara, all of the primary schools (50 primary schools, both government and private) used English for local content. Even, certain schools have cooperation with international institution to support English in their school. It seems that English becomes the most basic skill which should be mastered by their students. It is true that Badung is mostly visited by international tourists so the citizents should master English to get job in tourism industry.

Introducing English for young learners in the form of teaching English for young learners (TEYL) is important to be done in this era. It is actually a great educational policy as a way to face globalization (Johnstone, 2009). It prepares young learners to be competent in international communication. There are two main reasons why TEYL become so popular recently. First, it is assumed that early English learning helps better acquisitions (Nunan, 2003). If the students study English earlier, they become more competent than if it is studied later. Second, English competency is needed for surviving in economic globalization (Enever \& Moon, 2009). It can not be denied that globalization requires English as a medium of communication.

Based on the previous explanation, the students in elementary school or young learners should be taught English well. The students that are called as young learners have certain characteristics. According to (Suhartatik, 2008), they are categorized into young learners when they are in the age of 4 until 12 years old. It is explained that young learners' characteristics are: (1) moody, (2) having short attention span, (3) having high motivation on what they like, (4) high curiosity, (5) loving talking and concrete things, and (6) loving physical activities. Hence, this age is critical period for language acquisition. It is based on the genetic biology factor and sharp brain memorization (Yuvaraj, 2009). For those reasons, teaching English for young learners should be directed into the younger nature i.e like playing and singing. Here, teaching English can use games and song so they feel fun (Ratminingsih, 2018; Ratminingsih,2011). 
By the advance of information technology recently, the English teacher may use it to design creative and innovative learning such as using ICT. It is proven that TEYL is better if ICT are used to support it (Ratminingsih et al., 2018). In addition, the fast growth of technology makes teaching is not merely done in the classroom, but also through e-learning. Technology in education is used even more intensively during the outbreak of pandemic covid-19 in which learning should be done via online. E-learning is an instruction type and learning system where the students and the teacher get involved in the interchange of information, do not meet closely and separated by time (Alkhalaf et al., 2012). It means that e-learning is not limited by space and time. By using digital technology, learning is designed to be more interesting, enjoyable, and accessible for students (Oblinger \& Hawkins, 2005). In addition, e-learning has some benefits to be applied (Utami, 2018).

In designing or building e-learning up, various factors should be taken into account. Even though elearning is done without face to face interaction, but e-learning must be communicative, interactive, and collaborative (Sangrà et al., 2012). Learning can not be said as e-learning even though it uses information technologies. During the implementation of e-learning, the students must be able to communicate or interact with their friends and teachers. It is not only collecting assignment via email or other message services.

One of the issues in the implementation of e-learning hinges upon how to manage the students in online classroom. According to (Kumaravadivelu, 2011; Cameron 2003), classroom management becomes crucial issues in TEYL both in real classroom and virtual classroom. Classroom management is the usage of procedures and teaching methods which create an effective and efficient learning environment. Classroom management commonly involves various actions which are taken by teachers to establish order, involving students, and or elicit their cooperation (Emmer \& Stough, 2001). The class which is managed well influences the students' in learning foreign language. Well managed classroom makes the students feel comfortable and enjoy to study. If the classroom is not managed well, it impacts the students' learning achievement (Marzano, 2003).

Classroom management should be designed by considering some aspects, one of them is students' age. According to the (Guyana Ministry of Education, 2020), classroom management should be matched to the students' age. It means that the way to manage adults students is different from young learners. Different age has different characteristics which make classroom design should also be different to make the students feel secure to study and to facilitate the students' learning.

In the context of teaching young learners, the teachers need creative and innovative methods on designing classroom hence matched to the young learners' characteristics. Teaching for young learners is directed on the development of interaction, arising motivation, concrete materials and introducing of new words (Enever \& Moon, 2009). Arising the young learners' motivation becomes the most essential thing which should be concerned in teaching English (Cameron, 2003; Vernon, 2008). To arise the students' motivation, the teachers may give rewards for them.

Rewards is needed to give recognition for the student behavior and the character of the students. Rewards mean creativity of the teacher which give present, star, sticker, or any kinds of appreciation to the students for doing positive behavior or do great performance in the school (Aypay, 2018). The use of reward has purpose to make the students get the lesson and fun learning, encourage students' motivation and interest. The use of rewards is hope to help the teacher in teaching and learning English. Reward is matched to the characteristics of primary school in real school.

To know how rewards were applied by the teachers in real school especially in English lesson, the researcher conducted a preliminary observation in one of the primary schools in Bali, called Bali Kiddy Primary School. Bali Kiddy Primary School is located at Teuku Umar Barat street No. 235, Kerobokan. Bali Kiddy School is one of the primary schools in Bali which uses Indonesian curriculum but offers education beyond the minimum requirement of the national Indonesian accreditation authorities. It is caused by the additional subjects that the students should learn which are called international basic subjects. Besides that, Bali Kiddy school has reformed their learning into e-learning or online learning via google classroom and zoom.

The preliminary observation was done in first grade because this grade is a changed from kindergarten to elementary school level. In kindegraten, they are more playing than studying while in elementary school they start to study or enter academic field. Here, the students enter new learning atmosphere in which they start to concern on academic achievement, instead of playing. Furthermore, according to (Notoatmojo, 2012), low grade students tend to compare themselves with others especially in terms of achievement. They will do high efforts to get the best thing in which the other can not get it.

Based on the preliminary observation that was done in first grade, it was discovered that the students were motivated to study both in real or online classroom. They were enthusiastic to join class especially when question and answer session. In terms of reward, the teachers gave more reward in 
classical class than online classroom. Reward was given for the students who could answer questions correctly. Even, the students who make wrong answer were also given reward for appreciation.

Furthermore, structured interview was done to know the teachers and students' perceptions about the reward. Interview with the teachers was done in a break time, while interview with the students was done in the classroom by asking permission to school principal. From the interview, it was known that the teachers believed that rewards were one factor which brought positive effect on students' learning. For them, the reward can make the students study harder or it can make the students feel fun during studying. Meanwhile, some students were not interested with the reward given. They prefer to get sticker as the reward. They are less interested using reward which is in the form of star or pictures.

Some researches had been conducted to analyze the use of rewards in positive role (Loi, 2016; Chen \& Wu, 2010; Jovanovic, 2014). All researches discovered that rewards could influence the students' learning attitudes. It can raise the students' motivation to learn. They become more enthusiastics to study than without reward. The usage of reward should consider the students' needs and reward must be various.

Based on the explanation, it is urgent to do research relating the use of reward in teaching English in Bali Kiddy School. It is done based on four reasons. First, the learning was done via online mode hence investigating how rewards were and their effect was interesting to be done for further education. Second, knowing the type of reward applied by teachers and its effectivity help the teachers to design rewards for effective classroom. Third, the teachers' perception and students' perception about reward become factor which can influence the instructional design for young learners. Fourth, TEYL is challenged with the students' age in the playing phase, so by knowing the effectiveness of reward, it can be solution for the same problems in other children and school.

Based on the issues explained previously, this research aims at investigating a) kinds of rewards used in teaching English in Bali Kiddy School in online-learning, b) frequency of each reward used by the teacher in online-learning, c) in what context and for what purpose are rewards used in online-learning, d) the teachers' perception about the use of rewards in teaching English in online-learning, and e) the students' perception about the use of rewards in teaching English in online-learning

\section{Methods}

This qualitative research belongs to phenomenological study because it investigates various reactions to, or perceptions of, a particular phenomenon (Fraenkel \& Wallen, 2009). This research investigated the quality of phenomenon about the implementation of reward in Bali Kiddy School and perception of the students and teacher about providing reward in online learning context. From the reward, it is expected to describe the type of the reward usage, context of giving reward and their purpose.

This research was done in Bali Kiddy Primary School, especially in the first grade class. It was done along 2 months for data collection. It is started from the beginning of March until the end of April 2020. Then, it is continued with data analysis and research report. The subject of the research was the first grade teachers and students of Bali Kiddy which was 116 people. There are four English teachers teaching in this grade and there were 112 students in this grade.

To obtain the intended data, three methods were used, namely: observation, recording, and notetaking. In this study, the researcher utilized six instruments, namely: the researcher, observation sheet, interview guide, questionnaire, voice/video recorder and camera. The obtained data were analyzed qualitatively with Miles and Hubberman model.

\section{Result and Discussion}

Discussion of the findings can be divided into five. They can be explained in detail as follows.

\section{Kinds of Reward Used in Teaching English in Bali Kiddy School}

The result of data analysis for kinds of reward can be presented in the Table 1.

Tabel 1. Result of Data Analysis for Kinds of Reward

\begin{tabular}{ccc}
\hline No & Kinds of Reward & Example \\
\hline 1 & Verbal & 11 \\
2 & Tangible & 1 \\
\hline
\end{tabular}


Based on the Table 1, it can be justified that two types of reward are given to the students, verbal rewards and tangible reward. There are 11 verbal reward used in teaching English in Bali Kiddy School, namely: very nice, good job, fantastic, great, thank you for trying, excellent, perfect, well done, nice try, amazing, and awesome. Meanwhile, tangible reward or non-verbal reward is rarely given to the students because the learning is done in online mode by Zoom application. Here, tangible reward is given once by the teacher in the form of pencil, but it is not given to the students directly.

The finding indicates that the rewards given by the teachers are various. It is not only 1 until 5 terms, but it is until 11 for verbal rewards. The terms have been prepared by the teachers well to avoid students' boring. Every day, the teachers give exercise where the students are invited to get involve actively so the teachers should prepare many terms for reward (for verbal reward). It is especially because the class is done in online mode where the students and teacher are not in the same place. It makes giving verbal reward is the best solution for rewarding the students' performance.

Besides verbal reward, tangible reward (non-verbal reward) is also given by the teachers. However, it was given rarely because it is online learning. Based on the observation, only one teacher gives tangible reward, but it is symbolically. The reward is not given directly to the students. The reward can not be given directly to the students. In normal class, tangible reward is also given variously. However, it should be in the form of stationery or something related to education like: pencil, sharpener, etc. It is not recommended to give food or drink.

The giving of both verbal and tangible rewards indicates that the teachers create variations in using rewards. It is in line with (Drexler, 2010) who found out that teachers in the sample use some kind of reward in their classroom. Here, both verbal and tangible rewards are given for the students so the students will not get bored with the monotonous rewards (Bavelier et al., 2012). However, there is a different finding from this current research. Drexler's research shows that tangible rewards in the form of candy and snack are allowed to be given for the students.

Reward can serve as feedback for the students. Feedback enables to be better in learning because they can make improvement during learning process (Ratminingsih et al., 2018). Feedback which is given for the students both in oral and written form bring positive behaviors (Wheatley et al.,; Sanders et at., 2009). The feedback is also as an appreciation for the students' efforts. When the students are appreciated, they can increase their motivation so it brings positive effects on students' English achievement (Khansir \& Dehkordi, 2017).

The variety of using rewards is important to be done. Hence, rewards for the students should be modified or designed as creative as possible (Howard \& Jay, 2016). Instead of balancing verbal and tangible rewards, the variation is also done in each type of reward. In addition, the context of learning is also different, for instance online learning. In this mode of learning, the students' motivation should be kept since it influences students success in online learning (Harandi, 2015).

\section{The Frequency of Using Reward by the Teachers}

The result of data analysis for the frequency of reward is presented in the Table 2.

Tabel 2. Result of Data Analysis for the Frequency of Reward

\begin{tabular}{clcc}
\hline No & Kinds of Rewards & Frequency & Percentage \\
\hline 1 & Very nice & 31 & 8,45 \\
2 & Good Job & 68 & 18,53 \\
3 & Fantastic & 18 & 4,90 \\
4 & Great & 71 & 19,35 \\
5 & Thank you for trying & 16 & 4,36 \\
6 & Excellent & 49 & 13,35 \\
7 & Perfect & 14 & 3,81 \\
8 & Well done & 34 & 9,26 \\
9 & Nice Try & 13 & 3,54 \\
10 & Amazing & 17 & 4,63 \\
11 & Awesome & 35 & 9,54 \\
12 & Pencil & 1 & 0,27 \\
\hline
\end{tabular}

Based on the Table 2, it can be justified that the most frequent reward given to the students respectively are: great, good job, excellent, awesome, well done, very nice, fantastic, thank you for trying, 
perfect, and nice try. It indicates that verbal reward is given more than tangible reward. It is also supported by the interview with the teachers.

There are three reasons those rewards were given frequently based on the interview with the teachers. First, verbal reward is easy to be done. It is the simplest way of giving reward to the students. It is just by telling based on the rules, it is finished. Second, the students' answers are mostly right or nearly right. It can be seen from the verbal reward frequency, the rewards mostly indicate the students' answers are right. Third, if it were analyzed the frequency, the students are active during teaching and learning process. It can be seen from the number of the frequency of reward given by the teachers to the students.

This research is in line with (Casern, 2006) finding out that more frequent feedback (from more frequent tests and grade feedback) was more effective in boosting student performance. The feedback given in this research can be rewards and notes for the students' performance. Meanwhile, in this current research feedback is only reward (verbal or non-verbal). The feedback given in the form of reward is a mean of external intervention to behaviour and can be used for different purposes (Aypay, 2018).

Furthermore, (McClurg \& Morris, 2014) also discover that the frequency of rewards influences students' participation, where $84,52 \%$ of the students become active during quiz participation. However, this research does not investigate the use of reward in non formal quiz (question and answer non formal test). When they have intense rewards, they are stimulated to study or improve their competence (Chen \& Wu, 2010; Loi, 2016).

The use of reward for children is to motivate the students to learn especially for young learners. According to (Habibi \& Sofwan, 2015) young learners are different compared to teaching English to adults or young adults learners; they are more enthusiastic in the classrooms. This characteristic should be kept and improve so they can improve their performance in the classroom by providing ample rewards for the students. The more they get the reward, the more they feel appreciated. Then, they feel comfortable to learn.

In line with this, (Theodoteu, 2014) discovers rewards can reinforce and at the same time forestall young children's willingness to learn. For young education, reward is to stimulate children towards learning activities. The students are willing to join learning activities because they feel fun. The reward has direct or arise their willing to do efforts in the classroom. When they get appreciation in the form of reward, they may feel proud of himself.

\section{The Context Rewards that are Used and the Purpose of Using Rewards}

There are three contexts of giving rewards for the students, namely: the students' answers are perfect, the students' answers are nearly perfect, and the students' answers are mostly or totally wrong. Based on the observation which was followed by interview, it can be justified that reward is given in three contexts, namely : perfect (the students' answers are correct), nearly perfect (the students' answer is correct, but there are mistakes which can be tolerated) and need to improve (the students' answer is mostly or totally wrong). The giving of the reward has certain purpose, namely: perfect to keep the students' spirit to study, nearly perfect to make students more motivated to study, and need improvement to motivate the students to study and to avoid students'disappointment.

Keeping the students' willingness to study and motivating them to study should be done well by educators. (Chen \& Wu, 2010) state that reward can serve as reinforcement which increases the possibility of the desired behavior. Here, the behaviour like active participation during class is highly expected from the students. It is because by being active in the classroom, the students can build their knowledge. In this condition, rewards transform into extrinsic motivation which can make the students to do deeper understanding on learning materials (Tihidi \& Jabbari, 2012). For that reasons, reward that is given to the students should be able to direct the students into positive things.

In line with it, (Guendouze \& Abderrahim, 2012) reward can stimulate the students to increase their motivation in effective ways. For that reasons, reward should be given as effective as possible. If the teacher gives reward incorrectly, it might not match to the goal of reward. Here, the context must be a concern. Sometimes, the teacher should face-sensitive students so it should also be careful in giving reward.

In relation to young learners, their knowledge or performance is not only built by the teacher but also from environment. (Harmer, 2001) states that children must be provided with environment where they can see, hear, touch the materials and interact with others. It can be done by implementing teaching methods where they can do all activities like TPR and Drill (Ratminingsih, 2010). Besides that, the use of reward can be a way to do it. Rewards enables to the students to interact with others and teachers. When the students are given assignment, they will be motivated to answer if there is a reward. They will enthusiastically answer the questions and happy when they are correct or given reward. Even though their answer is wrong, the teacher also should be wise in giving reward for their contribution. 
Giving reward to the young learner is one way to shape their behaviour. As Lopez and Contero state that the match is giving of reward arises students' intrinsic motivation. The increasing of intrinsic motivation bring positive effect on students' achievement since they are bonded to each other. As it happens, learning goals can be achieved. Briefly, using reward is as the way to achieve learning goals.

In the case of online learning, reward can be one way to make online learning more alive and interactive. The problem of online learning is less of interaction (Ministry of Communication and Technology of New Zealand, 2008) so that it should be directed to be interactive. One way to do it by still giving reward in exercise, but it is in the form of verbal reward.

\section{Teachers' Perceptions about the Use of Rewards in Teaching English}

Based on the analysis result, it can be justified that all teachers agree that reward can bring positive effect on both academic and non-academic students and positive learning atmosphere. Moreover, the reward must be various based on the teachers' creativity. The reward should be designed as creative and positive as possible so the students can feel the reward is not boring and bring positive effect to their learning.

This finding is the same as (Drexler, 2010). In this thesis, it is discovered that the majority of teachers thought that rewards could help increase participation and academic achievement. Overall teachers did not feel that student's intrinsic motivation decreased when extrinsic rewards were given. Reward is viewed as the way to help them to achieve learning goals. In addition, all teachers in the sample use some kind of reward in their classroom. It indicates that the reward also should be various.

Furthermore, (Hoffmann et al., 2009) discovers that all teachers in our sample use some form of rewards in their classroom and the majority use some form of tangible rewards. Rewards were most frequently given for behaviour management, but there was a significant relationship between the use of rewards for behaviour and those given for academic achievement. Performance goal orientations for teaching were positively related to the use of tangible rewards and a higher degree of classroom control and negatively related to teacher self-efficacy. When asked to report on the appropriateness of using rewards in the classroom, only one-third of the teachers reported that they should be used conditionally.

In the context of teaching English reward serves as a trigger for motivation. (Fan \& Feng, 2012) state that highly motivated learners have been found to have higher achievement in learning English as a second language than those with lower motivation. The English teacher should stick in their mind that by giving reward, the students are directed to the better thing, both academic and non-academic. For that reason, the teachers should prepare strategic ways to design reward. As mentioned by (Utami et al., 2017), teachers need to always upgrade their knowledge and teaching skills to be an effective teacher.

In line with it, Khansir \& Dehkordi (2017) state that the role of motivation as one of the major important factors in learning English language can be regarded as a 'device' the learners of English use it in order to learn English. The same as it, Padmadewi (2018) finds out that reward could also improve reading habits and students' reading character. It proved that the reward could improve students' attitude and behaviour.

\section{Students' Perceptions about the Use of Rewards in Teaching English}

Based on the analysis result, it can be justified that 1) the students feel happy to get reward from their teacher, 2) reward motivates them to study, and 3) they get reward for both academic and nonacdemic things. In general, the students feel happy to get reward in learning. It is as trigger for them to be better in learning.

The students like to have reward frequently. They want to study harder if they got reward. They thought that the teacher will give the reward for those who is worthy to get it. Yet, the teachers should make consideration to give reward frequently since it can be monotonous and boring. It could demotivate the students. The frequency of giving the reward should consider the total activity at class. (Burton et al., 2003) stated that reward refers to anything that promotes a behavior being repeated in the future. By giving the reward, the students would be confidence and want to achieve the reward again. So, they would do their best again in the future in order to fulfill their goal to the get the reward.

(Cameron, 2003) states that children are often more enthusiastic and lively as learners. It makes the reward given is more meaningful for them. when the students are given it, they feel happy and proud of themselves. As the consequence, they are eager to study. It then makes them do harder efforts to achieve learning goals.

In line with it, (Deci et al., 2000), rewards can reinforce and at the same time forestall young children's willingness to learn. It will push them to study harder than without being given reward. (Davis et al., 2010) discover that reward history related significantly to students' motivational orientation and performance in college, and these relations were generally stronger for boys than for girls. The rewards 
stimulate the students into academic learning atmosphere where they can adapt themselves and create positive behaviors (Ilegbusi, 2013).

The use of reward as feedback is important to be considered. (Chen, 2016) reveals that feedback which provides support for further improvement is beneficial to learning and the benefit of rewards or feedback. The young learner get feedback (positive feedback), they will keep their spirit even improving it. They can feel that their learning environment is safe and comfortable.

Furthermore, (Payne, 2015) states that reward potentially affecting their ability to engage in all learning activities, the incentive of the school reward trip is universally effective, as is contact with home. Its effectiness brings image on students mind that reward is good thing for them. in relation to motivation, (Wilson \& Corpus, 2015) say that when the students have sense of control and choice, they increased intrinsic motivation, persistence, and belief. Here, by getting reward is one of their choice which directly affects their instrinsic motivation and persistent in studying.

Based on the findings and discussion, four implications can be drawn. First finding shows that both types of reward (verbal and tangible rewards) are given to the students, verbal reward and tangible reward. It implies that the teachers should keep giving rewards in both kinds as the way to motivate the students. By giving both kinds of rewards, there will be variations which can keep the students' spirit or enthusiasm.

Second finding shows verbal reward is more frequently used in online learning. It implies that the teachers should use various rewards out of 11 verbal rewards. It was done to give variations so the students will not get bored if those rewards always used. In addition, giving non-verbal reward can be done in more creative ways instead of just giving stationery. Next time, the students may get pin or something else as the reward.

Third finding shows reward is given in three context, namely: perfect (the students' answers are correct), nearly perfect (the students' answer is correct, but there are mistakes which can be tolerated) and need improve (the students' answer is mostly or totally wrong). The giving of the reward has certain purpose, namely: perfect to keep the students' spirit to study, nearly perfect to make students more motivated to study, and need improvement to motivate the students to study and to avoid students'disappointment. It implies that the teachers should keep the use of the context, but doing improvement in reward for nearly perfect and need improvement. For example, after giving reward "good", the teacher may asks " but there is a miss in this part, can you improve it?".

Fourth finding shows all teachers agree that reward can bring positive effect on both academic and non academic students and positive learning atmosphere. It implies that the teachers should keep using rewards and create more creative rewards for the students. in creating new rewards, all first grade teachers can do cooperation or make like special meeting to establish new rewards and their context of usage. Hence, there is a fix decision among teachers about the use of reward.

Fifth finding shows the students are happy and motivated when they get reward both for academic and non-academic. It implies that every effort of the students during learning English should get rewards. Here, the teachers should be sensitive for the efforts and ensure nobody who tries in doing something to get rewards. Furthermore, the teacher should also think about incorporating students' positive behaviour in their scoring criteria.

\section{Conclusion}

Based on the findings and discussions, there are 5 conclusions can be drawn concerning the research problems. First, the teachers use both verbal and tangible rewards in first grade students, but verbal reward is mostly used. Even though learning is done in virtually, the teachers try to give tangible reward which done symbolically. Here, the teachers show the rewards as if they get it like in the real world. Second, reward is given to the students highly. The most frequent reward given to the students respectively are: great, good job, excellent, awesome, well done, very nice, fantastic, thank you for trying, perfect, and nice try. Since it is virtual class, giving verbal reward will be the best choice. The teachers can directly give rewards by saying.

Third, reward is given in three contexts, namely: perfect, nearly perfect and need improvement with different purposes. Here, every students' effort get reward even though the mistakes are still made. It is as the way to keep the students' enthusiasm. Rewards are given to motivate the students. Fourth, all teachers agree that reward can bring positive effect on both academic and non-academic students and positive learning atmosphere. Moreover, the reward must be various based on the teachers' creativity. The teachers have positive point of view about rewards. It makes them apply rewards in the classroom as the way to improve the students' achievement and participation. Fifth, there are three perceptions of students relating to reward, namely: a) the students feel happy to get reward from their teacher, b) 
reward motivates them to study, and c) they get reward for both academic and non academic things. Commonly, they like to get reward. It is like there is a proud for them. The students' need appreciation in every effort they do.

\section{References}

Burton, A.B., Ray, G.E., and Mehta, S. (2003). "Children's Evaluations Peer Influence: The Role of Relationship Type and Social Situation". Child Study Journal, 33 (4), 235-255.

Cameron, L. (2003). Teaching Languages to Young Learners. UK: Cambridge University Press.

Cameron, L. (2014). Teaching languages to young learners. Cambridge: Cambridge University Press.

Casern, M. L. 2006. Active learning is not enough. Journal of College Science Teaching. Vol 35(6), 52-57. https://eric.ed.gov/?id=EJ752625

Chen, P. H. \& Wu, J. R. (2010). Rewards for reading: their effects on reading motivation. Journal of Instructional Pedagogies, 3(1), 1-8. https://files.eric.ed.gov/fulltext/EJ1097087.pdf

Deci, E.L., R. Koestner and R.M. Ryan (2001). Extrinsic Rewards and Intrinsic Motivation in Education: Reconsidered Once Again. Review of Educational Research, 71(1), 1-27. https://selfdeterminationtheory.org/SDT/documents/2001_DeciKoestnerRyan.pdf

Drexler, J. (2010). Teachers' Attitudes about Reward Systems in the Classroom. Theses. University of New York.

https://digitalcommons.brockport.edu/cgi/viewcontent.cgi?article=1024\&context=ehd_theses

Enever, J., \& Moon, J. (2009). New global contexts for teaching primary ELT: Change and challenge. In J. Enever, J. Moon \& U. Raman (Eds.), Young learner English language policy and implementation: International perspectives (pp. 5-21). Reading: Garnet Education.

Fan, J., \& Feng, H. (2012). A study on students' learning motivation of EFL in Taiwanese vocational college. International Journal of Learning and Development, 2(3), 260-269. http://dx.doi.org/10.5296 /ijld.v2i3.1791

Guendouze, M., \& Abderrahim, F. (2012). The Effects of Anticipation Rewards on Students' Motivation in Learning Grammar. Theses, University of Constantine. https://bu.umc.edu.dz/theses/anglais/GUE1307.pdf

Habibi, A. \& Sofwan, M. Teachers of English for Young Learners: An Analysis on Their English Proficiency and Profile. This paper has been presented at English Education Study Program-National Seminar, Faculty of Teacher Training and Education, Sriwijaya University, Palembang, October 3rd, 2015 .https://www.researchgate.net/publication/324184294_Teachers_of_English_for_Young_Learners_An _Analysis_on_Their_English_Proficiency_and_Profile/link/5ac46ad0a6fdcc1a5bd0201f/download

Harmer, J. (2001). The Practice of English Language Teaching. England: Pearson Education Limited.

Hoffman, K. F., Huff, J.D., Patterson, A.S., \& Nietfeld, J.L. (2009). Elementary Teachers' Use and Perception of Rewards in the Classroom. Teaching and Teacher Education, 25, 843-849. www.elsevier .com/ locate/ tate

Howard-Jones, P., \& Jay, T. (2016). Reward, Learning and Games. Current Opinion in Behavioral Sciences, 10(1), 65-72. Available at https://doi.org/10.1016/j.cobeha.2016.04.015

Johnstone, R. (2009). An early start: What are the key conditions for generalized success? In J. Enever, J. Moon \& U. Raman (Eds), Young learner English language policy and implementation: International perspectives (pp. 31-41). Reading: Garnet Education

Jovanovic, D. \& Matejevic. M. (2014). Relationship between Rewards and Intrinsic Motivation for Learning-Researches Review. Social and Behavioral Sciences. 149, 456 - 460 https://www.researchgate.net/publication/275544522_Relationship_between_Rewards_and_Intrinsic _Motivation_for_Learning_-_Researches_Review

Khansir, A. A. \& Dehkordi, F. G. (2017). The Role of Motivation in Teaching and Learning English Language. Modern Journal of language Teaching Methods (MJLTM) ,7(9), 179-191. https://mjltm.org/article-172-en.pdf 
Loi, D. P., \& Uyen. N. T. L. (2016). Motivating EFL Classroom Participation by Rewarding at a Language Center in Ho Chi Minh City, Vietnam. Journal of Applied Linguistics and Language Research, 3(5), 177-189. https://vhu.edu.vn/Resources/Docs/SubDomain/qlkh/378-1077-1PBLoidpUyenntlMotivatingEFLClassroomParticipationbyRewardingataLanguageCenterinHCMCityV ietnam.pdf

McClurg,L and Morris, R. (2014). Shaping Student Behaviors Through Reward Systems: Lessons From Beaver Trapping? Journal of Higher Education Theory and Practice, 14(2), 89-102. http://www.nabusinesspress.com/JHETP/McClurgL_Web14_2_.pdf

Nunan, D. (2003). The impact of English as a global language on educational policies and practices in the Asia-Pacific region.TESOLQuarterly, 37(4), 589-613. http://dx.doi.org/10.2307/3588214

Payne, R. (2015). Using Rewards and Sanctions in the Classroom: Pupils' Perceptions of Their Own Responses to Current Behaviour Management Strategies. Educational Review Journal, 67(4), 483504. https://www.tandfonline.com/doi/abs/10.1080/00131911.2015.1008407

Ratminingsih, N.M. (2010). Drills and Total Physical Response : An Attempt To Enhance Young Learners' Oral Communicative Competence. Jurnal Ilmu Pendidikan, 24(1), 19-28

Ratminingsih, N.M. (2011). Boosting Elementary School Students' Listening Skill Through Specially Created Songs. Lingua Scientia, 11(1), 1-20

Ratminingsih, N.M. (2018). Implementasi Board Games dan Pengaruhnya terhadap Hasil Belajar Bahasa Inggris. Jurnal Pendidikan dan Pengajaran, 43(18), 149 - 158

Ratminingsih, N.M., Mahadewi, L.P.P \& Divayana, D.G.H. (2018). ICT-Based Interactive Game in TEYL: Teachers' Perception, Students' Motivation, and Achievement. iJET, 13(9), 190-203

Ratminingsih, N.M., Marhaeni, A.A.I.N \& Vigayanti, L.P.D. (2018). Self-Assessment: The Effect on Students' Independence and Writing Competence. International Journal of Instruction, 11(3), 277-290. https://doi.org/10.12973/iji.2018.11320a

Suhartatik.(2008). Teaching English for Young Learners. Paradigma, 10(2), 193-200. http://journal.unnes.ac.id

Theodotou, E. (2014). Early Years Education: Are Young Students Intrinsically Or Extrinsically Motivated Towards School Activities? A Discussion about the Effects of Rewards on Young Children's Learning. Research in Teacher Education, 4(1).

Utami, I.G.A.L.P. (2018). The Online Learning of Teacher Profession Education Program (PPG) for Inservice English Teachers: Challenges and Accelerated Learning Factors. JPI, 7(2), 145-153

Utami, I.G.A.L.P., Saukah, A., Cahyono,B.Y., and Rachmajanti,S. (2017). Levels of Involvement in the English Teachers' CPD (Continuous Professional Development): The Degree of Professional Enthusiasm. The Journal of Asia TEFL, 14(2), 336-345

Vernon, S. A. (2008). Learn How to Make Teaching ESL to Preschool Children Magic and Fun. Teaching English Games. France: Les Anemos.

Wheatley, R.K, West, R.P., Charlton,C.T., Sanders,R.B., Smith, T.G., \& Taylor,M.J. (2009). Improving Behavior through Differential Reinforcement: A Praise Note System for Elementary Students. Education and Treatment of Children, 32(4), 551 -571 . https://psycnet.apa.org/record/2009-20795-004

Wilson, L.M \& Corpus, D.A. (2015). The Effects of Reward Systems on Academic Performance. Middle School Journal, 33(1), 56-60. https://doi.org/10.1080/00940771.2001.11495578 